\title{
BLAST FURNACE SLAG AND PINE BARK AS POTENTIAL FILTER MEDIA FOR METAL SORPTION FROM LANDFILL LEACHATE
}

\author{
Lena Johansson Westholm \\ Mälardalen University, Sweden
}

\section{ABSTRACT}

Heavy metals are commonly occurring in landfill leachate and in order to achieve the environmental goal about a non-toxic environment adopted by the Swedish Parliament, the leachate must be treated before being discharged into a nearby surface or groundwater body. There are several technical treatment options based on chemical, biological or physical processes. Examples of these techniques are the SBR technique, oxidation and membrane filtration. These treatment methods are not always suitable at all landfill sites due to economical and/or technical constraints. Other treatment methods have therefore attracted attention. These methods, often natural based such as constructed wetland systems, are more adapted to small landfill sites where high-tech and cost-demanding alternatives are not an option. One natural based method that has attracted attention for leachate treatment in recent years is the filter technique. It is based on the passage of a polluted water flow through a filter media with properties suitable for retention of heavy metals or other pollutants. A large number of different filter materials have been investigated with regard to their metal sorption capacity. The majority of these studies have been carried out in laboratory experiments of different kinds. Industrial by-products such as blast furnace slag and pine bark are filter materials that have been considered interesting for metal removal from landfill leachate. A series of laboratory experiments carried out as batch tests have therefore been conducted in order to learn more about the potential of these filter materials to remove heavy metals from landfill leachate.

\section{KEYWORDS}

Amorphous slag; Batch tests; Copper; Crystalline slag; Lead; Zinc

\section{INTRODUCTION}

There are about 300 active landfills in Sweden of which approximately 25 are regarded as large landfill [1]. At these landfills as well as at the smaller landfill sites, and for any other landfill in the world, landfill leachate is generated. The composition of leachate is dependent on the waste deposited at the landfill site as well as the phase of the landfill, thus landfill leachate at a specific landfill site is unique with regard to composition [2]. In addition, the composition of the leachate within a specified landfill site can also vary if several leachate streams are generated [3]. Commonly occurring pollutants in landfill leachates are ammonium, organic compounds and heavy metals. These pollutants should not be discharged 
into the environment without treatment. A various range of treatment methods have therefore been introduced, e.g. reverse osmosis, ammonium stripping and the SBR technique. These treatment methods are in the majority of cases efficient with regard to the removal of pollutants but on the other hand also very costly for the individual landfill operator.

The high costs and equally high energy input needed, have forced the landfill operators to find new treatment solutions. In recent years, different methods based on environmental engineering concepts have been proposed, for instance constructed wetland systems (CWS) and soil-water systems. One method that can be used solely or be included in a CWS for instance is the filter technique [4]. This technique is based on the passage of the polluted leachate through a special filter media which has demonstrated a high capacity to retain one or several pollutant(s). If necessary, several filter media can be used in combination.

Removal of heavy metals by different filter media is a vast area of research world over. A large number of researchers have investigated the sorption capacity of various groups of filter media such as minerals, organic residues and industrial by-products; see [5] for details. The majority of these filter media are however not easily available in Sweden thus other materials have attracted attention. Two of these are blast furnace slag (BFS) and pine bark, both industrial by-products from the steelworks and forest industries respectively. Blast furnace slag and pine bark have to some extent been investigated in laboratory experiments with regard to removal of heavy metals. The aim with this paper is to present additional investigations demonstrating the capacity of these filter media to remove heavy metals, especially with regard to landfill leachate.

\section{MATERIALS AND METHODS}

\subsection{Materials}

The filter media tested are blast fumace slag and pine bark. The former is a by-product derived from the process of separating iron from ore within the steel manufacturing industry. The slag tested originates from the steelworks in Oxelösund, approximately $100 \mathrm{~km}$ south of Stockholm, Sweden. The main components of the slag are calcium $(\mathrm{Ca})$, manganese $(\mathrm{Mg})$, silica $(\mathrm{Si})$, but aluminium $(\mathrm{Al})$ and sulphur $(\mathrm{S})$ are important components together with a range of different trace elements, see [6]. For other chemical and physical properties, see Table 1.

Two variants of the BFS were tested; amorphous and crystalline slag. The former has a porous structure while the latter has a more glassy structure. The differences in structure are due to different cooling processes; the amorphous slag (BFS-A) is rapidly cooled in water while the crystalline slag (BFS-C) is air-cooled. 
Table 1. Chemical and physical properties of blast furnace slag (from [6]).

\begin{tabular}{lll}
\hline Parameter & Crystalline BFS & Amorphous BFS \\
\hline $\mathrm{Ca}(\mathrm{mg} / \mathrm{kg})$ & 214410 & 214410 \\
$\mathrm{Fe}(\mathrm{mg} / \mathrm{kg})$ & 2735 & 3553 \\
$\mathrm{~K}(\mathrm{mg} / \mathrm{kg})$ & 4184 & 4225 \\
$\mathrm{Mg}(\mathrm{mg} / \mathrm{kg})$ & 104940 & 99512 \\
$\mathrm{Na}(\mathrm{mg} / \mathrm{kg})$ & 3865 & 4013 \\
$\mathrm{Si}(\mathrm{mg} / \mathrm{kg})$ & 159397 & 154722 \\
$\mathrm{Al}(\mathrm{mg} / \mathrm{kg})$ & 67744 & 67215 \\
$\mathrm{As}(\mathrm{mg} / \mathrm{kg})$ & 0.525 & 0.966 \\
$\mathrm{Ba}(\mathrm{mg} / \mathrm{kg})$ & 369 & 363 \\
$\mathrm{Cd}(\mathrm{mg} / \mathrm{kg})$ & 0.0186 & 0.0149 \\
$\mathrm{Co}(\mathrm{mg} / \mathrm{kg})$ & 10.8 & $<2$ \\
$\mathrm{Cr}(\mathrm{mg} / \mathrm{kg})$ & 42.3 & 30.2 \\
$\mathrm{Cu}(\mathrm{mg} / \mathrm{kg})$ & $<2$ & 4.56 \\
$\mathrm{Hg}(\mathrm{mg} / \mathrm{kg})$ & 0.132 & 0.139 \\
$\mathrm{Mn}(\mathrm{mg} / \mathrm{kg})$ & 4468 & 4164 \\
$\mathrm{Ni}(\mathrm{mg} / \mathrm{kg})$ & $<2$ & 2.42 \\
$\mathrm{~Pb}(\mathrm{mg} / \mathrm{kg})$ & 0.595 & 0.544 \\
$\mathrm{Sr}(\mathrm{mg} / \mathrm{kg})$ & 303 & 300 \\
$\mathrm{~S}(\mathrm{mg} / \mathrm{kg})$ & 10900 & 12900 \\
$\mathrm{~V}(\mathrm{mg} / \mathrm{kg})$ & 611 & 487 \\
$\mathrm{Zn}(\mathrm{mg} / \mathrm{kg})$ & 3.35 & 3.46 \\
$\mathrm{pH}$ Density $\left(\mathrm{g} / \mathrm{cm}^{3}\right)$ & $10.2-10.3$ & $10.3-10.6$ \\
$\mathrm{Porosity}(\%)$ & $1.2-1.61$ & $0.8-1.47$ \\
$\mathrm{Hydraulic}$ conductivity $(\mathrm{m} / \mathrm{day})$ & $40-58$ & $44-55$ \\
$\mathrm{Specific} \mathrm{surface}$ area $\left(\mathrm{m}^{2} / \mathrm{g}\right)$ & $0.8-15.9$ & $3.2-40.6$ \\
\hline & $0.5-0.7$ & $\mathrm{n} . \mathrm{a}$. \\
\hline
\end{tabular}

The pine bark used (Pinus sylvestris) is a by-product from the forest industry. The material originates from non-irrigated timber which is barked off at the saw-mill and thereafter delivered for use. The material is composed of a mixture of bark and wood fibre, see Table 2. The major components of these compounds are lignins and tannins. Other properties of the material can be seen in Table 2 .

Table 2. Chemical and physical properties of pine bark (Pinus sylvestris) (from [7]

\begin{tabular}{ll}
\hline Parameter & Pine bark \\
\hline Pine bark $(\%)$ & $85-90$ \\
Wood fibre $(\%)$ & $10-15$ \\
Density $\left(\mathrm{g} / \mathrm{cm}^{3}\right)$ & 0.25 \\
\hline
\end{tabular}




\subsection{Methods}

The blast furnace slag and the pine bark have been the subjects of numerous laboratory tests; e.g. batch tests in which a range of heavy metal solutions have been used in order to investigate the sorption capacities of the materials. The selected metals presented in this paper were copper $(\mathrm{Cu})$, lead $(\mathrm{Pb})$ and zinc $(\mathrm{Zn})$ since these metals are commonly occurring in landfill leachate according to [2].

\subsubsection{Batch tests}

Metal solutions were prepared in the laboratory using different metal salts. Stock solutions were prepared and diluted to various concentrations that ranged from $1.0-100 \mathrm{mg} / \mathrm{l}$; see also [8], [7] and [9] for further details. The $\mathrm{pH}$ of the solutions also varied; e.g. $\mathrm{pH} 4$ and $\mathrm{pH} 7$ were used in the tests. The metal solutions were added to a known volume of the filter media (ratio 5:50) and shaken for 60 seconds in all tests. The samples were thereafter analysed by means of atomic absorption spectrophotometer (AAS) (Vario 6). The difference between the initial concentration and the final concentration was assumed to be due to sorption.

\section{RESULTS}

\subsection{Metal sorption by blast furnace slag}

The results from the batch tests using blast furnace slag as filter media are presented in Figures 1-3. In Figure 1, results from a sorption experiment in which a $\mathrm{Cu}$-solution was used for sorption by BFS-A and BFS-C are presented.

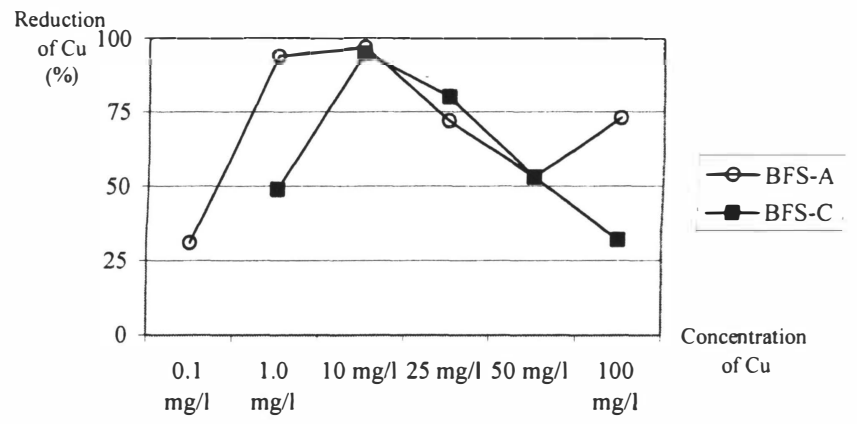

Figure 1. Examples of reduction of $\mathrm{Cu}$ by amorphous blast furnace slag (BFS-A) and crystalline blast furnace slag (BFS-C) at $\mathrm{pH} 7$ (adapted from [9]).

The results indicate that $\mathrm{Cu}$ is sorbed by both the amorphous and crystalline slag. The amorphous slag demonstrated a slightly better removal rate than the crystalline slag. This was the case also for $\mathrm{Pb}$ which also was removed by both slag types, and again, the amorphous slag demonstrated a more efficient removal rate than did the crystalline slag, see Figure 2. 


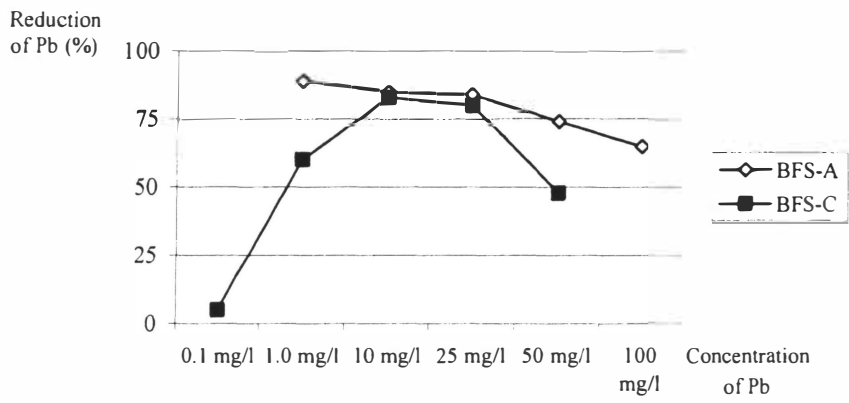

Figure 2. Examples of reduction of $\mathrm{Pb}$ by amorphous blast furnace slag (BFS-A) and crystalline blast furnace slag (BFS-C) at $\mathrm{pH} 7$ (adapted from [9]).

Zink did not show the same sorption pattern as $\mathrm{Cu}$ and $\mathrm{Pb}$. The removal rate for this metal was less than those for $\mathrm{Cu}$ and $\mathrm{Pb}$, and the $\mathrm{Zn}$-sorption decreased with increasing concentration, see Figure 3. In this case, the crystalline slag performed better than the amorphous slag.

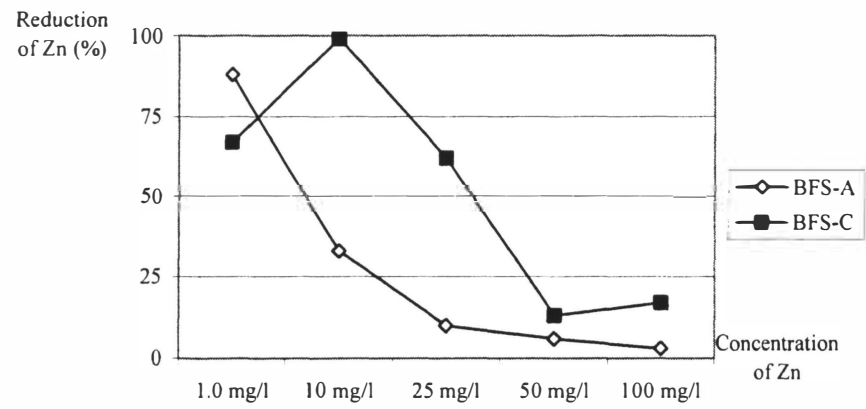

Figure 3. Examples of reduction of $\mathrm{Zn}$ by amorphous blast furnace slag (BFS-A) and crystalline blast furnace slag (BFS-C) at $\mathrm{pH} 7$ (adapted from [9]).

\subsection{Metal sorption by pine bark}

The removal rates of metals by pine bark are shown in Figures 4-6. Figure 4 shows the removal of $\mathrm{Cu}$ which is rather stable between 1.0 and $10 \mathrm{mg} / \mathrm{l}$, but thereafter it decreased slightly. 


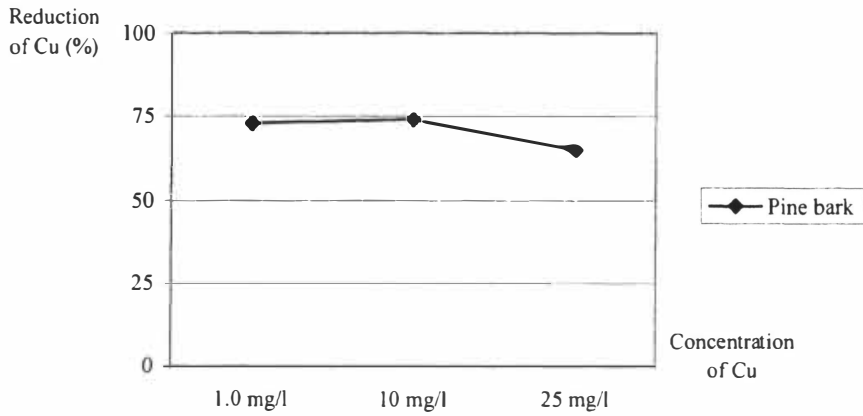

Figure 4. Examples of reduction of $\mathrm{Cu}$ by pine bark at $\mathrm{pH} 5$ (adapted from [7])

In Figure 5, the removal of $\mathrm{Pb}$ is shown. It can be seen that the removal is increasing but it should be noted that this phenomenon occurred at rather low concentrations, e.g. between 1.0 and $5.0 \mathrm{mg} / \mathrm{l}$.

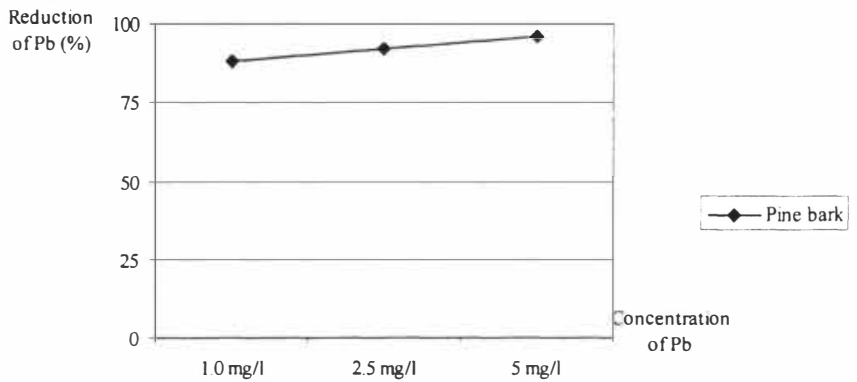

Figure 5. Examples of reduction of $\mathrm{Pb}$ by pine bark at $\mathrm{pH} 5$ (adapted from [7 7 )

The sorption pattern for $\mathrm{Zn}$ is shown in Figure 6. From the figure, a decreasing sorption can be observed. The removal of $\mathrm{Zn}$ is highest at the lowest concentration. 


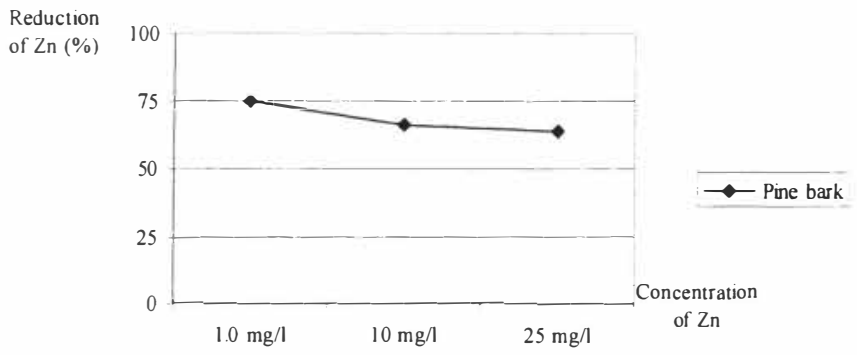

Figure 6. Examples of reduction of $\mathrm{Pb}$ by pine bark at $\mathrm{pH} 5$ (adapted from [7])

\section{DISCUSSION}

The results in the present paper indicate that both blast furnace slag and pine bark demonstrate an adequate capacity to sorb heavy metals from metal solutions. The results are in agreement with other similar investigations; see for instance [8], [10], [11] and [12]. It should however be kept in mind that the experiments described are carried out in the laboratory where conditions can be kept stable compared to the conditions in the field where they might vary considerable. Thus the results are therefore to be regarded as indicators of the filter media's capacity to sorb metals rather than a maximum value of the sorption capacity.

The batch tests have also been carried out with single metal solutions; e.g. there has been solely one metal species in the solution. In a real landfill leachate, the chance to find more than one metal is very large, and the results might therefore be completely different if using metal solutions or leachates with a more complex composition since competition for sorption sites might occur in that case. Further studies using multi-metal solutions and/or landfill leachates are therefore needed in order to learn more about the capacity by the filter media to sorb metals under more realistic conditions. An on-site column test indicates that the metal sorption capacity is more various and less efficient in the field than in the laboratory investigations presented in the present paper [3].

All metals were however sorbed to the filter media tested, in particular copper and lead which demonstrated a high affinity regardless of $\mathrm{pH}$ and concentrations used. This might be due to the fact that these metals are strongly adsorbing metals; e.g. strongly bound to humic substances and variable-charged particles surfaces in the soil [13]. Zinc is also an adsorbing metal but its mobility depends on the $\mathrm{pH}$-value to a much larger extent than for the other metals tested.

The fact that the filter media tested sorb metals at various metal concentrations also vouch for removal of metals from different types of landfill leachates. A landfill will undergo several stages depending on the degradation of the waste it contains. The landfill leachate generated at the different stages will reflect the degradation processes leading to variations in metal concentrations in the leachate for instance. 
Further on, the amorphous blast furnace slag seemed to be more efficient than the crystalline blast furnace slag with regard to sorption of the metals in general, and $\mathrm{Cu}$ and $\mathrm{Pb}$ in particular. This might be explained by the properties of the slag types. The amorphous slag is much more porous than the crystalline one, thus allowing a more efficient sorption due to larges sorption sites available.

Compared to the slag materials, the pine bark is also an efficient filter media with regard to sorption of metals. The pattern is the same for the different metals; copper and lead are sorbed to a larger extent than zinc. The same reasons can be quoted as for the slag materials.

\section{CONCLUSIONS}

The laboratory investigations that have been carried out demonstrate the both the blast furnace slag and the pine bark are capable of sorbing heavy metals. In general the amorphous slag demonstrates a higher sorption capacity than the crystalline slag. The pine bark has also performed well indicating that this media is interesting for further investigations. Further studies are however needed in order to learn more about the filter media behaviour when fed with multi-metal solutions and/or landfill leachate.

\section{ACKNOWLEDGEMENTS}

Thanks to Bastien Schnell, Camille Godron, Sophie Lucet and Grégory Collet, all students at PolyTech'Orléans, France, who worked hard in the laboratory helping to put forward the research within this thrilling field of research. Ann-Sofie Magnusson and Christina IngwallJohansson, both at the department of Public Technology, Mälardalen University, are also thanked for assistance in the laboratory as well as for valuable discussions.

\section{REFERENCES}

[1] Johansson, B., 1997. Stadens tekniska system - Naturresurser i kretslopp. Byggforskningsrådet T17:1997, Stockholm, Sweden (in Swedish).

[2] Öman, C., Malmberg, M., Wolf-Watz, C., 2000. Utveckling av metoder för karaktärisering av lakvatten från avfallsupplaga- Slutrapport, RVF rapport 00:3 (in Swedish).

[3] Johansson Westholm, L., Nehrenheim, E., Waara, S., 2005. Filterbehandling av lakvatten på deponin Lilla Nyby, Eskilstuna - Slutrapport. Forskningsrapport ISt MdH 2005:7, Department of Public Technology, Mälardalen University, Västerås, Sweden (in Swedish).

[4] Johansson Westholm, L., 2004. Constructed wetlands for treatment of land fill leachate experiences from Sweden and Norway. VATTEN 60(1), 7-14.

[5] Johansson Westholm, L., Färm, C., 2004. Treating polluted water flows with filter technique - Theory and experiences. Research Report 2004:7, Department of Public Technology, Mälardalen University, Västerås, Sweden.

[6] Johansson Westholm, L. Lind, L., Nehrenheim, E. Sorption of phosphorus from domestic wastewater by blast furnace slag - theory and practical experiences (manuscript in preparation)

[7] Collet, G., 2005. Pine bark as filter material - Sorption and desorption tests with regard to heavy metals. Diploma Work, Department of Public Technology, Mälardalen University, Västerås, Sweden. 
[8] Godron, C., Lucet, S., 2005. Blast furnace slag for metal removal from metal solutions Crystalline and amorphous blast furnace slag for copper, lead, nickel and zinc. Diploma work, department of Public Technology, Mälardalen University, Västerås, Sweden.

[9] Schnell, B., 2004. Removal of heavy metals using slag material. Diploma work, Department of Public Technology, Mälardalen University, Västerås, Sweden.

[10] Dimitrova, S.V., 1996. Metal sorption on blast furnace slag. Water Research 30(1), 228232.

[11] Dimitrova. S.V., 2002. Use of granular slag columns for lead removal. Water Research 36, $4001 \mathrm{a} 4008$.

[12] Al-Asheh, S., Duvnjak, Z., 1997. Sorption of cadmium and other heavy metals by pine bark. Journal of Hazardous Materials 56(35), 35-51.

[13] Gustafsson, J-P., Jacks, G., Simonsson, M., Nilsson, I., 2004. Soil and Water Chemistry. Department of Land and Water Resources Engineering, KTH, Stockholm, Sweden. 